\title{
PENGARUH PENAMBAHAN TEPUNG PISANG GOROHO TERHADAP MUTU SNACK FOOD
}

\section{EFFECT OF ADDITION OF BANANA GOROHO FLOUR ON THE QUALITY OF SNACK FOOD}

\author{
Judith Henny Mandei ${ }^{1}$, Fetty Indriayty ${ }^{2)}$ \\ Balai Riset dan Standarisasi Industri Manado \\ Jalan Diponegoro No.21-23 Manado \\ *Hp 08124443392, e-mail: nenimandei@yahoo.com
}

\begin{abstract}
ABSTRAK
Snack food adalah makanan yang dikonsumsi di antara waktu makan utama dan umumnya sudah merupakan bagian yang tidak bisa ditinggalkan dalam kehidupan sehari-hari terutama pada kalangan anakanak remaja. Telah dilakukan penelitian variasi penggunaan tepung pisang goroho dengan tepung tapioka pada snack food. Tujuan penelitian untuk mendapatkan formulasi snack food yang menggunakan bahan baku tepung pisang goroho dan tepung tapioka. Penelitian ini menggunakan metode deskriptif yang ditampilkan dalam bentuk grafik dan gambar dengan perlakuan yaitu $A=20 \%$ tepung pisang goroho:80\% tepung tapioka; $\mathrm{B}=30 \%$ tepung pisang goroho:70\% tepung tapioka; $\mathrm{C}=40 \%$ tepung pisang goroho:60\% tepung tapioka; $\mathrm{D}=$ $50 \%$ tepung pisang goroho:50\% tepung tapioka; $E=60 \%$ tepung pisang goroho: $40 \%$ tepung tapioka; $F=70 \%$ tepung pisang goroho:30\% tepung tapioka; $\mathrm{G}=80 \%$ tepung pisang goroho:20\% tepung tapioka; $\mathrm{H}=100 \%$ tepung pisang goroho : $0 \%$ tepung tapioka. Hasil penelitian ini menunjukkan bahwa snack food dengan formulasi tepung pisang goroho $40 \%$ dan tepung tapioka $60 \%$ (C) merupakan perlakuan yang dapat direkomendasikan dengan tingkat kesukaan terhadap rasa 3,8 (suka) warna 4,68 (sangat suka), tekstur 3,96 (suka) kadar air 3,1\%, kadar lemak 36,32\%, protein 5,16, kadar abu 1,49\% serat 0,34\%.

Kata kunci: Pisang goroho, snack food, mutu
\end{abstract}

\begin{abstract}
Snack food is a food consumed between the main meal times and already become a part in our everyday life, especially among teenagers. Variations with using of banana goroho flour with tapioca flour have been done for snack food. The purpose of this research is to get snack food formulation using raw material of banana goroho and tapioca flour. This research used descriptive method which is shown in graphic form and image with different treatments. $A=20 \%$ banana goroho flour: $80 \%$ tapioca flour; $B=30 \%$ banana goroho flour: $70 \%$ tapioca flour; $C=40 \%$ banana goroho flour: $60 \%$ tapioca flour; $D=50 \%$ goroho banana flour: $50 \%$ tapioca flour; $E=60 \%$ banana goroho flour: $40 \%$ tapioca flour; $F=70 \%$ banana goroho flour: $30 \%$ tapioca flour; $G=80 \%$ banana goroho flour: $20 \%$ tapioca flour; $H=100 \%$ banana goroho flour: $0 \%$ tapioca flour. The results of this study indicate that formulation snack food with $40 \%$ banana goroho flour and $60 \%$ tapioca flour (C) was recommended with taste preferences of 3.8 (like) color 4.68 (very like), texture 3, 96 (like) 3.1\% water content, $36.32 \%$ fat content, 5.16 protein, ash content $1.49 \%$ fiber $0.34 \%$.
\end{abstract}

Keywords: Goroho bananas, snack food, quality

\section{PENDAHULUAN}

Pisang (Musa paradisiaca) merupakan salah satu komoditas holtikultura yang berpeluang sangat tinggi sebagai bahan diversifikasi pangan, food security dan agribisnis di Indonesia. Potensi ini bukan saja karena karbohidrat, mineral dan kandungan seratnya yang sangat memenuhi persyaratan sebagai komoditi pangan dan makanan diet tetapi juga permasalahan yang timbul pada saat panen di mana jumlah pisang melimpah dan menumpuk terutama di sentra produksi pisang [1]. 
Penggunaan pisang goroho, pada umumnya diolah menjadi pisang goreng, rebus dan keripik. Pengolahan pisang goroho menjadi tepung memberi peluang pengembangan yang lebih bervariasi. Tepung pisang adalah salah satu cara pengawetan pisang dalam bentuk olahan. Tepung pisang mempunyai rasa dan bau yang khas sehingga dapat digunakan pada pengolahan berbagai jenis makanan yang menggunakan tepung di dalamnya. Pengolahan pisang menjadi tepung agar mempunyai masa simpan lebih lama, lebih mudah dalam pengemasan dan pengangkutan, lebih praktis untuk diversifikasi produk olahan, serta mampu memberi nilai tambah buah pisang.

Pengembangan produk dari pisang goroho pada penelitian ini yaitu pengembangan produk makanan ringan atau snack food. Jenis snack food yang dibuat yaitu kue telur gabus yang merupakan kue tradisional Indonesia, berbentuk kecil kembung panjang, berwarna kuning agak keemasan, bertekstur halus, tidak pecahpecah serta berasa gurih dan renyah yang dibuat dengan cara digoreng. Biasanya menggunakan bahan baku tepung tapioka dan telur. Dalam penelitian ini sebagian tepung tapioka diganti dengan tepung pisang goroho.

Snack food atau dikenal dengan makanan ringan ialah makanan yang dikonsumsi diantara waktu makan utama dan umumnya sudah merupakan bagian yang tidak dapat ditinggalkan dalam kehidupan sehari-hari [2][9]. Menurut Booth (1998), yang termasuk dalam snack food di antaranya ialah permen dan produk konfeksioneri; cookies/cracker dan produk asal tepung lainnya; acar dan saus; meat snacks, snack berbasis susu; fish snacks dan shellfish snacks, extruded snacks; snack berbasis buah; kacang-kacangan; potato-based texture snacks; dan health food snacks [9].

Tepung adalah partikel padat yang berbentuk butiran halus atau sangat halus tergantung proses penggilingannya. Biasanya digunakan untuk keperluan penelitian, rumah tangga, dan bahan baku industri. Tepung pisang goroho adalah tepung yang berasal dari pengolahan pisang goroho menjadi tepung. Pengolahan pisang goroho menjadi tepung memberi peluang pengembangan yang lebih bervariasi, yang secara tidak langsung ikut membantu percepatan pencapaian program ketahanan pangan.

Tepung pisang goroho mengandung gizi yang cukup tinggi yaitu karbohidrat $75,18 \%$, protein $5,16 \%$, lemak $0,97 \%$, terdiri dari amilosa $39,59 \%$ dan amilopektin 31,19\%. Kadar air tepung pisang goroho yaitu $11,99 \%$, total gula $1,83 \%$, pati $80,89 \%$, dan serat kasar 2\% [3]. Dari data tersebut terbukti bahwa potensi pengembangan pisang goroho sebagai alternatif makanan bersumber karbohidrat karena mengandung pati yang tinggi.

Beberapa penelitian yang telah dilakukan dengan menggunakan bahan baku tepung pisang goroho yaitu diantaranya pembuatan beras analog berbasis tepung pisang goroho dengan bahan pengikat CMC [4] biskuit berbahan baku tepung pisang 
goroho [5], pengaruh bahan perendaman pada proses pembuatan tepung pisang goroho [6].

Tapioka sering disebut sebagai tepung. Tapioka biasanya digunakan sebagai bahan pengental kuah ataupun sebagai bahan pengisi pada kue-kue kering. Bahan pangan ini merupakan pati yang diekstrak dengan air dari umbi singkong. Setelah disaring, bagian cairan dipisahkan dengan ampasnya. Cairan hasil saringan kemudian diendapkan. Bagian yang mengendap tersebut selanjutnya dikeringkan dan digiling hingga diperoleh butiran-butiran pati halus berwarna putih, yang disebut tapioka.

Penggunaan tapioka pertama kali diduga berasal dari Amerika Selatan. Kata tapioka berasal dari bahasa Brasil tipioka, yang berarti makanan dari singkong. Di Inggris, tapioka diidentikkan dengan rice pudding karena paling umum digunakan sebagai bahan baku untuk membuat pudding [7].

Pengeringan merupakan metode pengeluaran atau pengurangan sebagian besar air dari suatu bahan pangan dengan cara memindahkan air, sehingga kondisi kadar air bahan seimbang dengan kadar air udara normal atau kondisi kadar air bahan sesuai dengan nilai aktivitas air yang aman dari kerusakan mikrobiologi, kimiawi, dan enzimatis [10]. Kandungan air dalam bahan pangan merupakan faktor yang paling dominan sebagai penyebab kerusakan bahan pangan setelah lepas panen. Pada tingkatan kadar air yang cukup tinggi setelah panen, maka kegiatan biologis dalam bahan pangan masih tetap berlangsung. Kegiatan tersebut adalah secara biokimia dan kimia, seperti aktivitas enzim, respirasi, dan mikrobiologis sehingga bahan pangan menjadi cepat rusak hingga akhirnya busuk [11].

Penggorengan adalah suatu proses pemanasan bahan pangan menggunakan medium minyak goreng sebagai pengantar panas. Tujuan dari proses penggorengan adalah untuk melakukan proses pemanasan pada bahan pangan, pemasakan dan pengeringan pada bahan pangan yang digoreng. Pada proses penggorengan akan terjadi pemanasan pada bahan pangan dengan suhu tinggi. Pemanasan dengan suhu tinggi akan membentuk dekstruksi panas yang mampu membunuh mikroba dan menginaktivasi enzim yang terdapat pada bahan pangan tersebut. Pemasakan dan penggorengan akan menurunkan aktivitas air $\left(A_{W}\right)$ bahan pangan baik pada bagian permukaan, maupun pada seluruh bagian produk pangan. Aktivitas air yang menurun akan mengurangi ketersediaan air dalam bahan pangan tersebut untuk digunakan oleh mikroba perusak dan pembusuk sehingga umur simpanan produk menjadi lebih panjang. Dengan melakukan penggorengan, bahan pangan mentah akan mengalami pemasakan. Proses pemasakan akan meningkatkan mutu makanan (eating quality) karena pada saat pemasakan terjadi konversi zat gizi ke dalam bentuk yang lebih sederhana dan dapat dicerna manusia. [12] Penelitian ini bertujuan untuk mendapatkan formulasi snack food yang menggunakan 
bahan baku tepung pisang goroho dan tepung tapioka.

\section{BAHAN DAN METODE}

\section{Bahan dan Alat}

Bahan-bahan yang digunakan dalam penelitian adalah tepung pisang goroho, tepung tapioka, telur, garam mentega, minyak goreng dan bahan untuk pengemasan. Peralatan yang digunakan adalalah oven, grinder, pisau, talenan, panci stanless steel, kompor, mixer, loyang plastik pengaduk dan wajan.

\section{Metode Penelitian}

Penelitian ini dilakukan dalam 2 tahap yaitu:

1. Membuat tepung pisang goroho

2. Membuat snack food dengan formulasi variasi penggunaan tepung pisang goroho dan tapioka yaitu:

$A=20 \%$ tepung pisang goroho : $80 \%$ tepung tapioka

$\mathrm{B}=30 \%$ tepung pisang goroho : $70 \%$ tepung tapioka

$C=40 \%$ tepung pisang goroho : $60 \%$ tepung tapioka

$D=50 \%$ tepung pisang goroho : $50 \%$ tepung tapioka

$E=60 \%$ tepung pisang goroho : $40 \%$ tepung tapioka

$\mathrm{F}=70 \%$ tepung pisang goroho : $30 \%$ tepung tapioka

$G=80 \%$ tepung pisang goroho : $20 \%$ tepung tapioka

$H=100 \%$ tepung pisang goroho : $0 \%$ tepung tapioca
Setiap perlakuan formulasi diulang 2 kali.

\section{Tahapan Pekerjaan}

a. Pembuatan Tepung Pisang Goroho

Buah pisang disortir dari kotoran dicuci kemudian diblansir dalam air panas dengan suhu $90^{\circ} \mathrm{C}$ selama 15 menit. Kemudian didinginkan, dikupas dan ditimbang. Setelah itu diiris tipis dengan menggunakan slicer. Irisan pisang selanjutnya, dikeringkan dengan menggunakan alat pengering pada suhu 60 ${ }^{\circ} \mathrm{C}$ selama 10 jam. Setelah itu didinginkan pada suhu ruang kemudian dihaluskan dengan menggunakan grinder dan diayak dengan menggunakan 80 mesh. Tepung pisang goroho dikemas dengan menggunakan pengemas plastik.

b. Pembuatan Snack Food

Disiapkan wadah ukuran sedang untuk membuat adonan. Ditimbang tepung tapioka dan tepung pisang goroho sesuai perlakuan, ditambahkan garam $0,5 \%$ dan keju parut $25 \%$. Campur dan aduk bahan kering menggunakan spatula sampai semua bahan tercampur sempurna. Masukkan telur sebanyak $50 \%$ sedikit demi sedikit ke dalam bahan kering tadi sambil diaduk. Diulangi sampai telur habis, ditambahkan margarin $30 \%$ diaduk sampai adonan terasa kalis. Adonan yang sudah kalis, dibentuk dan dicetak kemudian dimasukkan ke dalam wajan yang berisi minyak goreng (suhu kamar). Selanjutnya disiapkan wajan yang sudah berisi minyak goreng dan dipanaskan. Adonan yang sudah disiapkan dipindahkan ke dalam wajan yang sudah dipanaskan. Setelah warnanya kuning diangkat dan 
ditiriskan. Setelah snack food dingin dilakukan pengemasan.

c. Pengamatan

Pengamatan terhadap snack food meliputi uji analisis kadar air (SNI 01-28911992)[13], kadar lemak (SNI 01-28911992)[13], kadar abu (SNI 01-2891-1992)[13], serat (SNI 01-2891-1992)[13]. Uji organoleptik dengan menggunakan skala hedonik (rasa, warna dan tekstur) dengan skala $1-5$, nilai 5 (sangat suka), 4 (suka), 3

Tabel 1. Hasil analisis kimia tepung tapioka

\begin{tabular}{lcc}
\hline \multicolumn{1}{c}{ Parameter } & Satuan & Hasil \\
\hline Kadar air & $\%$ & 5,69 \\
Lemak & $\%$ & 0,21 \\
Protein & $\%$ & 0,41 \\
Serat & $\%$ & 0,08 \\
Kadar abu & $\%$ & 0,12
\end{tabular}

\section{b. Tepung Pisang Goroho}

Tabel 2. Hasil analisis kimia tepug pisang goroho

\begin{tabular}{lcc}
\hline \multicolumn{1}{c}{ Parameter } & Satuan & Hasil \\
\hline Kadar air & $\%$ & 8,37 \\
Lemak & $\%$ & 0,06 \\
Protein & $\%$ & 2,53 \\
Serat & $\%$ & 10,24 \\
Kadar abu & $\%$ & 0,76 \\
\hline
\end{tabular}

\section{Pembahasan}

Analisis Kimia Snack Food Variasi Penggunaan Tepung Pisang Goroho Dengan Tepung Tapioka

a. Kadar Air

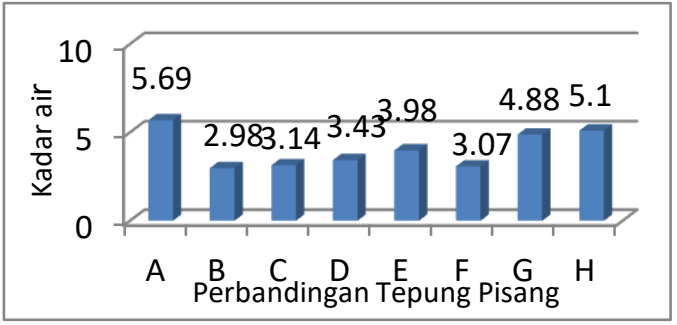

Gambar 1. Histogram analisis kadar air variasi penggunaan tepung pisang goroho dengan tepung tapioka pada snack food 
Keterangan: $\mathbf{A}=20 \%$ tepung pisang goroho:80\% tepung tapioka; $\mathbf{B}=30 \%$ tepung pisang goroho:70\% tepung tapioka; C $=40 \%$ tepung pisang goroho:60\% tepung tapioka; $\mathbf{D}$ $=50 \%$ tepung pisang goroho:50\% tepung tapioka; $\mathbf{E}=60 \%$ tepung pisang goroho:40\% tepung tapioka; $\mathbf{F}=70 \%$ tepung pisang goroho:30\% tepung tapioka; $\mathbf{G}=80 \%$ tepung pisang goroho:20\% tepung tapioka; $\mathbf{H}=100 \%$ tepung pisang goroho:0\% tepung tapioka

Berdasarkan hasil analisis kadar air dari snack food dapat dilihat pada Gambar 1, yaitu berkisar 2,98-5,69\%. Produk snack food yang dihasilkan diperoleh kadar air yang bervariasi. Hal ini diduga pada proses penggorengan produk snack belum terukur karena tidak menentukan waktu dan suhu penggorengan, sehingga pengaruh penambahan tepung pisang goroho tidak terlihat.

Kadar air dari snack food yang dihasilkan berkaitan dengan sifat higroskopis tepung tapioka dan tepung pisang goroho yang sebagian besar komponen adalah pati yang bersifat yang mudah menyerap air[14]. Kadar pati tepung pisang goroho 80,89\%[3], sedangkan kadar pati tepung tapioka sekitar $85 \%[21]$. Secara teori semakin banyak penambahan tepung pisang goroho kadar air semakin kecil. Kemampuan untuk mengikat air dari pati disebabkan karena jumlah gugus hidroksil dengan molekul pati sangat besar. Semakin besar kadar pati maka semakin banyak air yang terserap sehingga kadar air semakin tinggi. Kadar air yang dipersyaratkan dalam SNI 2886:2015 Makanan Ekstrudat yaitu maksimal $4 \%[15]$.

\section{b. Kadar Lemak}

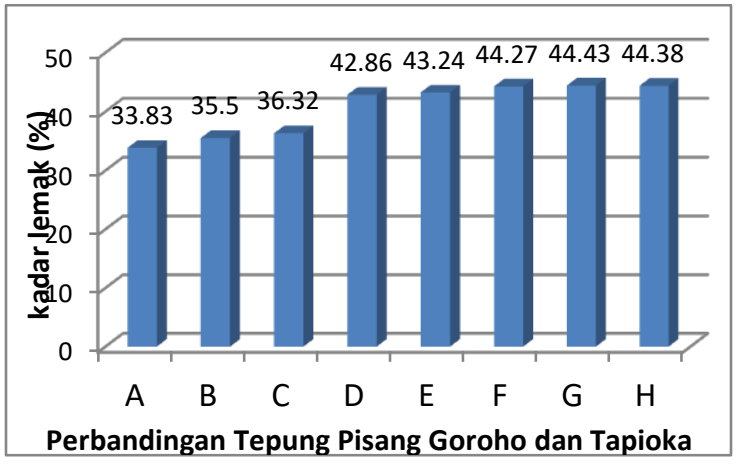

Gambar 2. Histogram analisis kadar lemak variasi penggunaan tepung pisang goroho dengan tepung tapioka pada snack food

Keterangan: $\quad \mathbf{A}=20 \%$ tepung pisang goroho:80\% tepung tapioka; $\mathbf{B}=30 \%$ tepung pisang goroho:70\% tepung tapioka; $\mathbf{C}=40 \%$ tepung pisang goroho:60\% tepung tapioka; $D=50 \%$ tepung pisang goroho:50\% tepung tapioka; $\mathbf{E}=60 \%$ tepung pisang goroho:40\% tepung tapioka; $\mathbf{F}=70 \%$ tepung pisang goroho:30\% tepung tapioka; $\mathbf{G}=80 \%$ tepung pisang goroho:20\% tepung tapioka; $\mathbf{H}=100 \%$ tepung pisang goroho:0\% tepung tapioka

Berdasarkan hasil analisis kadar lemak snack food (Gambar 2) yang dihasilkan yaitu berkisar 33,83-44,43\%. Lemak terendah diperoleh pada produk snack food dengan penambahan tepung pisang goroho $20 \%$ dan tapioka $80 \%$, diperoleh kadar lemak 33,83\%. Setiap bahan-bahan pangan yang digoreng mengandung sejumlah lemak yang diabsorbsi. Semakin besar formulasi tepung pisang goroho, maka tingkat penyerapan minyak semakin tinggi[16]. Hal ini berhubungan dengan kandungan protein dari bahan baku tepung pisang goroho $(2,53 \%)$ yang lebih tinggi dari tepung tapioka $(0,46 \%)$. Protein mempunyai gugus yang bersifat non 
polar (bersifat lipofilik) sehingga dapat mengikat lemak/minyak [20].

Lemak dan minyak merupakan sumber energi yang efektif dibandingkan dengan karbohidrat dan protein. Satu gram minyak atau lemak dapat menghasilkan 9 kkal. Minyak yang digunakan dalam penelitian ini adalah minyak goreng sawit. Minyak goreng sawit mengandung asam miristat 1,1-2,5, asam palmitat $40-46$, asam stearat $3,6-4,7$, asam oleat 30-45, asam linoleat 7-11 [16]. Minyak atau lemak nabati mengandung asam-asam lemak esensial seperti asam linoleat, linolenat dan arakidonat yang dapat mencegah penyempitan pembuluh darah akibat penggumpalan kolesterol [17]. Kadar lemak snack food yang dihasilkan bervariasi hal ini diduga berkaitan erat dengan absorbs atau tingkat penyerapan minyak pada snack food. Kadar lemak dengan proses penggorengan yang dipersyaratkan dalam SNI 2886:2015 yaitu maksimal 38\% (b/b)[15]. Penambahan tepung pisang goroho sampai $40 \%$ menghasilkan produk snack food yang kadar lemaknya masih memenuhi syarat mutu.

c. Kadar Protein

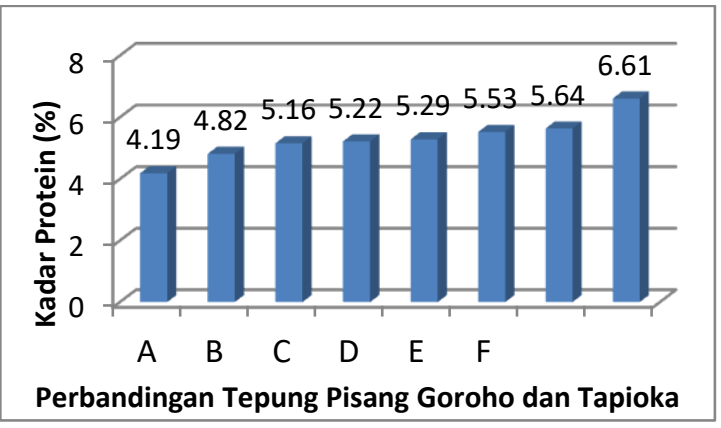

Gambar 3. Histogram analisis kadar protein variasi penggunaan tepung pisang goroho dengan tepung tapioka pada snack food
Keterangan: $\quad \mathbf{A}=20 \%$ tepung pisang goroho:80\% tepung tapioka; $\mathbf{B}=30 \%$ tepung pisang goroho: $70 \%$ tepung tapioka; C= $40 \%$ tepung pisang goroho:60\% tepung tapioka; $\mathbf{D}=50 \%$ tepung pisang goroho:50\% tepung tapioka; $E=60 \%$ tepung pisang goroho:40\% tepung tapioka; $\mathbf{F}=70 \%$ tepung pisang goroho:30\% tepung tapioka; $\mathbf{G}=80 \%$ tepung pisang goroho: $20 \%$ tepung tapioka; $\mathbf{H}=100 \%$ tepung pisang goroho:0\% tepung tapioka

Hasil analisis kadar protein snack food dengan variasi penggunaan tepung pisang goroho dengan tepung tapioka yaitu berkisar antara 4,19-6,61\%. Dari Gambar 3, terlihat bahwa cenderung terjadi kenaikan kandungan protein pada snack food dengan semakin tinggi penambahan tepung pisang goroho. Kadar protein pada tepung pisang goroho yaitu, 2.53 dan tepung tapioka $0.46 \%$. Kandungan protein snack food yang diperoleh selain dari bahan baku tepung goroho dan tapioka, juga diperoleh dari penggunaan bahan lainnya seperti telur ayam, margarin dan keju.

d. Kadar Abu

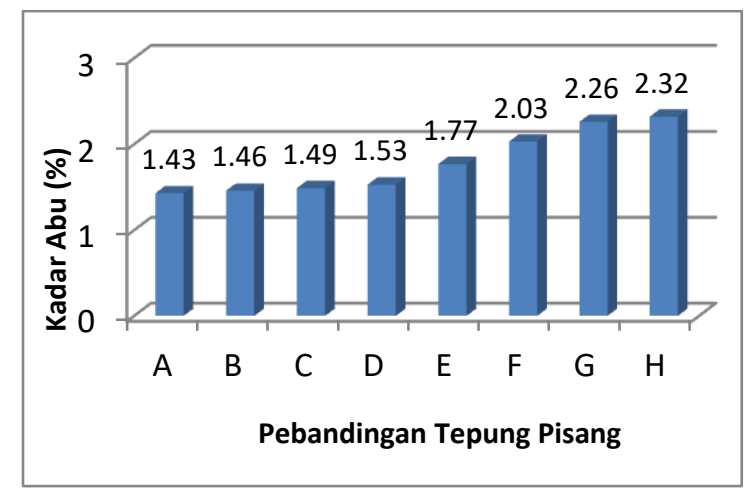

Gambar 4. Histogram analisis kadar abu variasi penggunaan tepung pisang goroho dengan tepung tapioka pada snack food 
Keterangan: $\quad \mathbf{A}=20 \%$ tepung pisang goroho:80\% tepung tapioka; $\mathbf{B}=30 \%$ tepung pisang goroho:70\% tepung tapioka; $\mathbf{C}=40 \%$ tepung pisang goroho:60\% tepung tapioka; $\mathbf{D}=50 \%$ tepung pisang goroho:50\% tepung tapioka; $\mathbf{E}=60 \%$ tepung pisang goroho:40\% tepung tapioka; $\mathbf{F}=70 \%$ tepung pisang goroho:30\% tepung tapioka; $\mathbf{G}=80 \%$ tepung pisang goroho:20\% tepung tapioka; $\mathbf{H}=100 \%$ tepung pisang goroho:0\% tepung tapioka.

Analisis kadar abu snack food dengan variasi penambahan tepung tapioka dan tepung pisang goroho yaitu berkisar 1,432,23\% dapat dilihat pada Gambar 4. Kadar abu menunjukkan besarnya kandungan mineral produk snack food.

Gambar 4 menunjukkan bahwa penambahan tepung pisang goroho dengan persentasi yang lebih besar, nilai kadar abu pada snack food semakin meningkat. Kadar abu produk dipengaruhi oleh kadar abu dari bahan baku tepung, yang berarti bahwa kadar abu tepung pisang goroho lebih tinggi dari kadar abu tepung tapioka. Berdasarkan hasil penelitian, kadar abu tepung pisang goroho putih adalah 2,29\% [22], sedangkan tepung tapioka di pasaran di persyaratkan sesuai SNI01-2997-1996 harus memiliki kadar abu $<0,6 \%$.

Kadar abu menunjukkan besarnya kandungan mineral pada produk snack food. Abu adalah zat-zat organik yang terdiri dari unsur-unsur mineral.

e. Serat Kasar

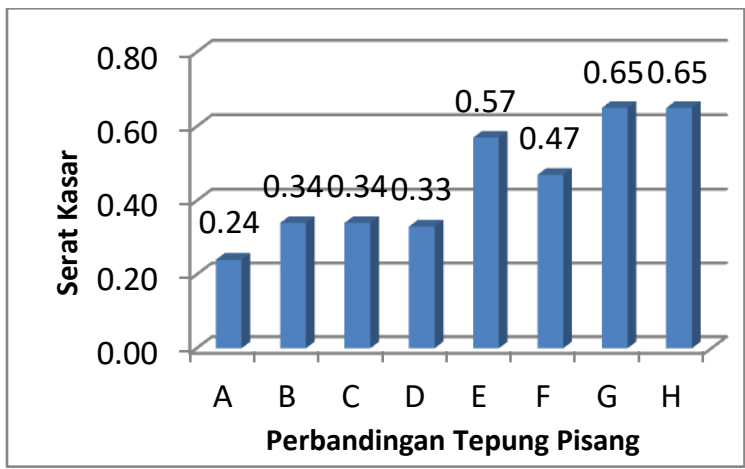

Gambar 5. Histogram Analisis Serat Kasar Variasi Penggunaan Tepung Pisang Goroho Dengan Tepung Tapioka Pada Snack Food

Keterangan: $\quad \mathbf{A}=20 \%$ tepung pisang goroho:80\% tepung tapioka; $\mathbf{B}=30 \%$ tepung pisang goroho:70\% tepung tapioka; $\mathbf{C}=40 \%$ tepung pisang goroho:60\% tepung tapioka; $D=50 \%$ tepung pisang goroho:50\% tepung tapioka; $\mathbf{E}=60 \%$ tepung pisang goroho:40\% tepung tapioka; $\mathbf{F}=70 \%$ tepung pisang goroho:30\% tepung tapioka; $\mathbf{G}=80 \%$ tepung pisang goroho:20\% tepung tapioka; $\mathbf{H}=100 \%$ tepung pisang goroho:0\% tepung tapioka

Serat termasuk bagian dari makanan yang tidak mudah diserap dan sumbangan gizinya dapat diabaikan, namun serat makan sesungguhnya mempunyai fungsi penting yang tidak tergantikan oleh zat lainnya. Angka kecukupan serat yang dianjurkan adalah 25g/1000 kal. Bagi orang dewasa 19$30 \mathrm{~g} / \mathrm{kap} /$ hari sedangkan bagi anak 10-14 g/1000 kkal. [18] Produk pangan mengandung serat kasar tinggi, dapat mengganggu penyerapan zat-zat gizi, protein, lemak, vitamin dan mineral yang dibutuhkan oleh tubuh. Kadar serat yang tinggi dapat menyebabkan perut cepat 
kenyang karena mempunyai daya penyerapan air yang tinggi.

\section{Uji Organoleptik Tingkat Kesukaan Snack} Food Variasi Penggunaan Tepung Pisang Goroho dengan Tepung Tapioka

\section{Rasa}

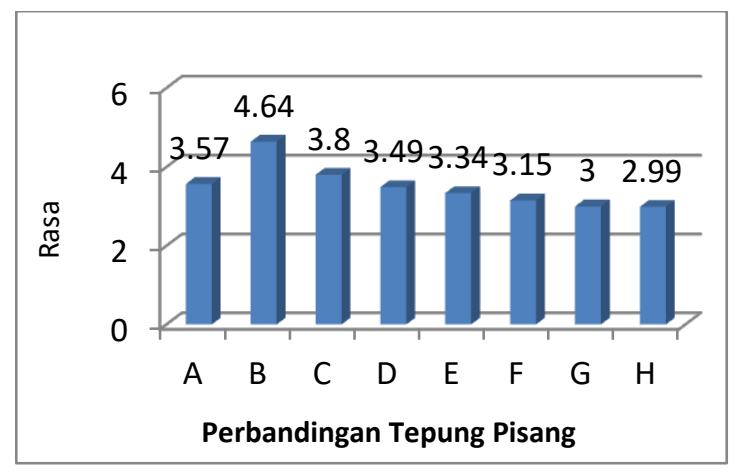

Gambar 6. Histogram analisis tingkat kesukaan terhadap rasa snack food variasi tepung pisang goroho dengan tepung tapioka

Keterangan: $\quad \mathbf{A}=20 \%$ tepung pisang goroho:80\% tepung tapioka; $\mathbf{B}=30 \%$ tepung pisang goroho:70\% tepung tapioka; $\mathbf{C}=40 \%$ tepung pisang goroho:60\% tepung tapioka; $\mathrm{D}=50 \%$ tepung pisang goroho:50\% tepung tapioka; $\mathbf{E}=60 \%$ tepung pisang goroho:40\% tepung tapioka; $\mathbf{F}=70 \%$ tepung pisang goroho:30\% tepung tapioka; $\mathbf{G}=80 \%$ tepung pisang goroho:20\% tepung tapioka; $\mathbf{H = 1 0 0 \%}$ tepung pisang goroho:0\% tepung tapioka.

Uji organoleptik tingkat kesukaan: 1. Sangat tidak suka; 2. Tidak suka; 3. Agak suka;

\section{Suka; 5. Sangat suka}

Hasil uji organoleptik tingkat kesukaan terhadap rasa dari snack food dengan variasi penambahan tepung pisang goroho dan tapioka yaitu rata-rata berkisar 2,99-4,64 (agak suka sampai sangat suka) dapat dilihat pada Gambar 6. Semakin banyak tepung pisang goroho yang ditambahkan nilai kesukaan terhadap rasa snack food cenderung semakin menurun. Kecuali pada penambahan tepung pisang dari $20 \%$ ke $30 \%$ terjadi peningkatan nilai kesukaan. Nilai tertinggi tingkat kesukaan terhadap rasa pada perlakuan variasi tepung pisang goroho $30 \%$ dan tepung tapioka $70 \%$ yaitu berkisar 4,64 (sangat suka). Pada perlakuan ini memiliki formulasi tepung pisang goroho dan tepung tapioka yang sesuai hingga rasa yang dihasilkan lebih disukai. Hal ini dikarenakan campuran tepung pisang goroho dan tepung tapioka tidak ada yang dominan sehingga memunculkan rasa snack food yang disukai panelis [14]:

\section{Warna}

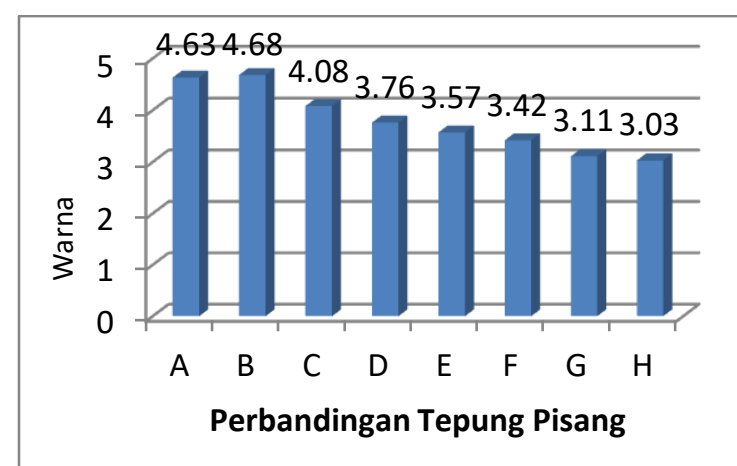

\section{Gambar 7. Histogram analisis tingkat kesukaan terhadap warna snack food variasi tepung pisang goroho dengan tepung tapioka}

Keterangan: $\mathbf{A}=20 \%$ tepung pisang goroho:80\% tepung tapioka; $\mathbf{B}=30 \%$ tepung pisang goroho:70\% tepung tapioka; $\mathbf{C}=40 \%$ tepung pisang goroho:60\% tepung tapioka; $D=50 \%$ tepung pisang goroho:50\% tepung tapioka; $\mathbf{E}=60 \%$ tepung pisang goroho:40\% tepung tapioka; $\mathbf{F}=70 \%$ tepung pisang goroho:30\% tepung tapioka; $\mathbf{G}=80 \%$ tepung 
pisang goroho:20\% tepung tapioka; $\mathbf{H = 1 0 0 \%}$ tepung pisang goroho:0\% tepung tapioka

Uji organoleptik tingkat kesukaan: 1. Sangat tidak suka; 2. Tidak suka; 3. Agak suka; 4.Suka; 5. Sangat suka

Hasil pengujian organoleptik tingkat kesukaan terhadap warna dari snack food dengan perlakuan variasi penambahan tepung pisang dan tepung tapioka rata-rata yaitu berkisar 3,03-4,68 (agak suka sampai sangat suka), seperti pada Gambar 7. Warna snack food yang dihasilkan yaitu warna kuning muda sampai coklat. Penambahan tepung pisang yang lebih banyak akan menghasilkan warna yang lebih coklat, warna ini diduga dihasilkan dari senyawa fenol dan tannin yang terdapat pada pisang goroho. Menurut Nurali dkk (2012), pisang goroho mengandung senyawa fenol $0,05 \%$ dan tannin $0,13 \%$ sehingga pada waktu mengolahan tepung pisang goroho masih memungkinkan terjadinya browning[2].

\section{Tekstur}

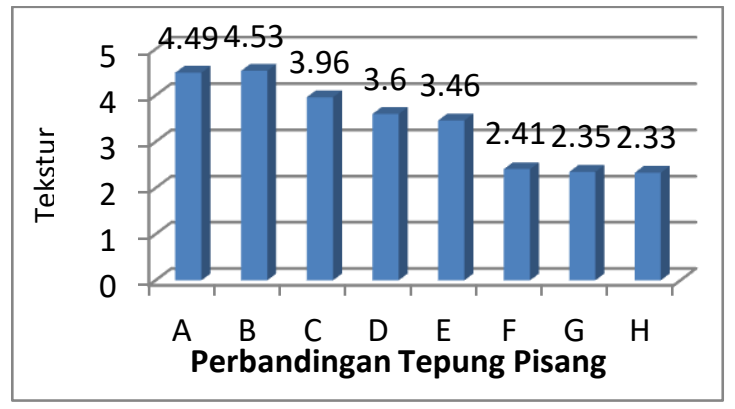

Gambar 8. Histogram Analisis Tingkat Kesukaan terhadap Tekstur Snack Food Variasi Tepung Pisang Goroho Dengan Tepung Tapioka

Keterangan: $\quad \mathbf{A}=20 \%$ tepung pisang goroho:80\% tepung tapioka; $\mathbf{B}=30 \%$ tepung pisang goroho: $70 \%$ tepung tapioka; $\mathbf{C}=40 \%$ tepung pisang goroho:60\% tepung tapioka; D $=50 \%$ tepung pisang goroho:50\% tepung tapioka; $\mathbf{E}=60 \%$ tepung pisang goroho:40\% tepung tapioka; $\mathbf{F}=70 \%$ tepung pisang goroho:30\% tepung tapioka; $\mathbf{G}=80 \%$ tepung pisang goroho:20\% tepung tapioka; $\mathbf{H}=100 \%$ tepung pisang goroho:0\% tepung tapioka Uji organoleptik tingkat kesukaan: 1. Sangat tidak suka; 2. Tidak suka; 3. Agak suka; 4.Suka; 5. Sangat suka

Hasil pengujian organoleptik terhadap tingkat kesukaan terhadap tekstur (Gambar 8) dari snack food dengan perlakuan variasi penambahan tepung pisang dan tepung tapioka yaitu rata-rata berkisar 2,33-4,53 (tidak suka sampai sangat suka). Pada perlakuan variasi penambahan tepung pisang goroho $30 \%$ dan tapioka $70 \%$ nilai tingkat kesukaan terhadap tekstur dari snack food yang tertinggi yaitu 4,53 (sangat suka).

Perlakuan variasi penambahan tepung pisang lebih besar menyebabkan nilai tingkat kesukaan terhadap tekstur menurun. Tekstur memegang peran penting bagi penerimaan konsumen. Produk snack food yang memiliki penerimaan tertinggi adalah yang tidak mudah rapuh. Proses penggorengan pada suhu tinggi juga akan menyebabkan terjadinya penguapan sebagian air dalam bahan pangan. Pengeringan tersebut akan membentuk tekstur renyah yang disukai pada produk gorengan. [12] Tergantung pada "mutu" tujuan produk akhir yang digoreng, maka kadar air bahan yang dirgoreng memegang peranan penting. Produk-produk yang dikonsumsi dengan kondisi "renyah" biasanya didapatkan dari bahan yang telah 
dikeringkan hingga kadar airnya mencapai minimum atau serendah mungkin [19].

\section{KESIMPULAN DAN SARAN}

\section{Kesimpulan}

Snack food dengan formulasi tepung pisang goroho $40 \%$ dan tepung tapioka $60 \%$ (C) merupakan perlakuan yang dapat direkomendasikan dengan tingkat kesukaan terhadap rasa 3,8 (suka) warna 4,68 (sangat suka), tekstur 3,96 (suka) kadar air 3,1\%, kadar lemak $36,32 \%$, protein 5,16, kadar abu $1,49 \%$ serat $0,34 \%$.

\section{Saran}

Perlu untuk dilakukan pengembangan pembuatan snack food bahan baku tepung pisang goroho dengan varian cita rasa.

\section{DAFTAR PUSTAKA}

1. Suryanti dan Supriyadi, A. Pisang. Penebar Swadaya. Jakarta. 2012.

2. Nurali, E. J. N., Djarkasi G. S. S. dan Lalujan, E. L. The Potential of Goroho Plantain as a Source of Fuctional Food. Laporan Hasil Penelitian Tropical Plant Curiculum Project in Cooperation with USAIDTEXAS A\&M University. 2012.

3. Sondakh. Kandungan Pati pada Beberapa Varietas Pisang. Skripsi Jurusan Teknologi Pertanian Unsrat. Fakultas Pertanian Unsrat. Manado. 1990.

4. Gideon H, P., Nurali, E., Koapaha, T., Lalujan, L. Pembuatan Beras Analog Berbasis Tepung Pisang Goroho (Musa acuminate) Dengan Bahan Pengikat Carboxymethyl Cellulose (CMC). Jurusan Teknologi Pertanian. Fakultas Pertanian Unsrat. Manado. 2012.

5. Frisly, S, Nurali, E. J. N. Karakteristik Fisikokimia Biskuit, Berbahan Baku Tepung Pisang Goroho. Fakultas Pertanian Unsrat. Manado. 2013.
6. Sjamsiwarni, R.S dan Fetty, I. Pengaruh bahan perendaman pada proses pembuatan tepung pisang goroho. Jurnal Penelitian Teknologi Industri. No.2 Desember. 2015.

7. Anonim. Tepung Tapioka, Manfaatnya, dan Cara Pembuatannya. https://aremaipb.wordpress.com/2010/02/ 11/tepung-tapioka-manfaatnya-dan-carapembuatannya.. [12 Agustus 2016].

8. Muchtadi T.R., Purwiyatno., dan Basuki. A. Teknologi Pemasakan Ekstrusi. LSI IPB. Bogor. 1988.

9. Booth, R. G. Snack Food. Van Nostrand Reihold. New York. 1990.

10. Syah, D. Pengantar Teknologi Pangan. IPB. Bogor. 2012.

11. Afianti, L. H. Teknologi Pengawetan Pangan. Alfabeta. Bandung.

12. Muchtadi, T. R dan Sugiono. 2014. Prinsip dan Teknologi Pangan. Alfabeta. Bandung. 2012.

13. Badan Standardisasi Nasional. SNI 01-28911992. Cara Uji Makanan Minuman.

14. Aristawati, R.W., Atmaka, W., Muhammad, D.R.A. Substitusi Tepung Tapioka (Manihot esculenta) dalam Pembuatan Takoyaki. Jurnal Teknosains Pangan. Surakarta. 2013.

15. Badan Standardisasi Nasional. SNI. 01-37771995 Tentang Persyaratan Makaroni.

16. Ketaren, S. Pengantar Teknologi Minyak dan Lemak Pangan. Cetakan Pertama. UIPress. Jakarta. 1986.

17. Winarno, F. G. Kimia Pangan dan Gizi. PT. Gramedia Pustaka Utama. Jakarta. 1991.

18. Kustanto, C. M. Sifat Makanan dan Peranannya Bagi Kesehatan. Jurnal Gizi dan Pangan. November 2006 1(2):45-54.

19. Nurhidayah dan Aminah, S. Chips Tempe sebagai Makanan Ringan Alternatif Pengganti Junk Food. Universitas Muhamadiyah Semarang. http://jurnal.unimus.ac.id.

20. Kusnandar, F. 2010. Kimia Pangan Komponen Mikro. PT Dian Rakyat, Jakarta. 
21. Amin, N. A. Pengaruh Suhu Fosforilasi Terhadap Sifat Fisikokimia Pati Tapioka

Termodifikasi. PS IImu dan Teknologi Pangan Fak. Prertanian Universitas Hassanudin Makassar (Skripsi). 2013.

22. Nurali, E., Djarkasi, G., Sumual, M dan Lalujan E. The Potential of Goroho Plantain As a Source of Functional Food. Final Report Tropical Plant Curriculum Project in Cooperation with USAID-TEXAS A\&M University. 2012. 